\title{
AC 2007-348: INTEGRATING TEAMWORK ACROSS THE CURRICULUM
}

\section{Charlie Edmonson, University of Dayton}

Charlie P. Edmonson is an Associate Professor and Program Coordinator of Industrial Engineering Technology at the University of Dayton. Prior to joining the faculty at UD, he retired from the U. S. Air Force after 30 years of engineering design, industrial engineering, and experience at various levels of management.

\section{Donna Summers, University of Dayton}

DONNA C.S. SUMMERS, Ph.D. is a Professor of Industrial Engineering Technology at the University of Dayton. Her major areas of concentration are Quality Assurance and Human Factors. She holds a Bachelor of Science in Mechanical Engineering from the University of Cincinnati and a Master of Science in Industrial Engineering from Purdue University. She obtained her Doctorate in Industrial Engineering from the University of Cincinnati. 
Session

\title{
Integrating Teamwork Across the Curriculum
}

\begin{abstract}
The ability to work on teams is a very important business skill. Some educators choose to call it a "soft skill." However, our Industrial Advisory Committee members and the businesses hiring our graduates choose to call it a "critical skill". The Technology Accreditation Commission of the Accreditation Board for Engineering and Technology recognizes the importance of being able to work on teams. In the Criteria for Accrediting Engineering Technology Programs, Criterion 2e requires that "An engineering technology program must demonstrate that graduates have an ability to function effectively on teams." How can instructors ensure that our students learn how to work effectively on teams? How can we teach our students teamwork and team leadership skills?

The traditional approach to developing team work and team leadership skills involves assigning students randomly to teams, giving them a project to work on, and expecting them to somehow magically learn to work together effectively as leaders and members of teams. This "they'll learn about teamwork if they work on teams" approach fails to give students adequate preparation and insight into teamwork and team management skills. It doesn't work. A coordinated approach to teambuilding and leadership skills training is needed to effectively prepare students to work on teams. This paper describes how the Engineering Technology Department at the University of Dayton works together to provide graduates the skills to be able to function effectively on teams.
\end{abstract}

\section{Introduction}

Gone are the days when engineers sat behind a drawing board and pitched their designs over the wall to manufacturing. Today, our graduates must be able to work together successfully with other engineers and people from other disciplines to accomplish the company's objectives. Working in teams promotes synergy; the results of the team are greater than the sum of the efforts of the individual team members. Industry seeks to hire employees who not only have required technical skills, but who also have some skill in working on and leading teams. The challenge for academia is to prepare graduates who have this combination of skills.

Learning about teamwork through lectures may give students information about teamwork skills but does not supply the experience necessary to be able to effectively apply those skills. Merely putting students in groups and hoping that they will learn about teamwork by being in the groups is not enough to ensure that they learn teamwork skills. A group becomes a team when it shares a common goal and works together successfully to achieve that goal. Michael Prince ${ }^{4}$ said that students need to experience being on successful teams to understand and appreciate the values of good teamwork. According to Stephanie Adams ${ }^{8}$, when individuals have an effective teaming experience, 
individual team members as well as the team as a whole will grow in their understanding of teaming constructs and proper synergy of task and team processes will occur.

Development of teamwork skills takes time. A structured approach is necessary to train students to work on teams.

In the Engineering Technology Department at the University of Dayton, students learn to work on teams by learning teamwork skills in two lecture courses and then applying those skills by working on team projects that are woven throughout the curriculum. Teamwork training begins in the first year. In the First Year Seminar course, SET-100, students work in teams on a design project. In SET-101, Enrichment Workshop, firstyear students work in teams to accomplish their homework in the math and science courses. All Engineering Technology majors are required to take the Project Management Course, IET-323, where teamwork is taught. In the Project Management course, students also work in teams to accomplish an actual project. As an applicationsoriented discipline, many engineering technology courses include team projects. This team project experience is culminated in the interdisciplinary capstone course, Senior Project, XXX-490, where teams of students complete a project with industry. How each of these courses teach and apply teamwork, leadership training, and team projects are described below.

\section{First Year Courses}

Two courses taken by students in their first year involve working in teams. SET-100, First Year Seminar, is required by all students in the first semester of their first year. Besides team dynamics, topics such as academic policies, academic planning, registration procedures, and counseling and career placement services are discussed. Professional ethics, critical thinking and communications, and are also discussed.

Following an introduction to team dynamics, the students work in teams to accomplish a design project. One such project is to design and build a marble maze. The teams are given a set of materials such as coat hangers, cardboard, glue, etc. to use to build the maze. The maze must be freestanding, and not supported or attached to any other structure. The maze must include certain design criteria such as spirals, jumps, loops, and ramps. When the projects are completed, the teams participate in a maze competition with faculty in attendance and acting as judges. The team's design that takes the longest time for the marble to go through the maze is the winner. The complexity of the project requires multiple team meetings to design and redesign the maze. During this interaction, students have the opportunity to apply team skills.

The Enrichment Workshop, SET-101 is required for all Engineering Technology students in their first two semesters. The workshop is structured to provide collaborative learning for first-year Engineering Technology students. Students work in teams to accomplish homework in math, chemistry, physics, and other first year courses. In this setting, they practice team skills while problem solving. 


\section{Project Management Course}

In businesses, cross-functional teams try to complete major projects on time, within budget, and to customer specifications. The Project Management course, IET-323, is required for all Engineering Technology majors. The course is taken in either the sophomore or junior year by engineering technology students and the course is also a popular elective course for business school students. Students are expected to use the skills learned in the Project Management course to manage projects in subsequent courses.

In this structured course, students are taught tools and techniques to use in order to successfully complete a project for a business. A variety of skills are needed to work together effectively. Four skills are emphasized in the Project Management course: understanding others, negotiating, time management, and conducting effective meetings. These four skills, as identified by the employers who hire our graduates, are taught in such a way as to help the student internalize the information for later use. IET-323, Project Management is structured to both teach and apply these skills.

\section{Understanding people}

Teams are composed of individuals and their individual personalities will affect team performance. Team leaders and members need to recognize each individual's knowledge and skill base so that the individuals can be assigned tasks that utilize these skills effectively. Another key to helping teams function more effectively is knowledge of team members' personalities. Teams comprised of many different personality types are better able to grasp the entire problem or project. Ned Herrmann's Four-Quadrant Personalities are used to help students understand the different personality types that they may encounter in their teams. When students understand that different personality types will approach the same problem in different ways, they can work together more effectively in a team. Teaching students about these personality types can help them become better team members. Summing up personality types and team interactions is a presentation titled "Working with Difficult People." By focusing attention on how to avoid being labeled a difficult person, this lecture covers important considerations for providing and receiving both positive and negative feedback. The emphasis is placed on being part of the solution, not part of the problem.

Having provided insight into the different types of personalities found in teams, the course focuses on the team itself. When personalities are combined, a group of people takes on a dynamic singular to the group. All teams go through stages of development and all teams will face problems. Lectures cover the four stages of team development as first described by Peter Scholtes ${ }^{9}$ in the Team Handbook: forming, storming, norming, and performing. Following this, the students discuss ten beneficial team behaviors including clear communication, ground rules, and balanced participation. A discussion of ten common team problems and what to do about them follow this. This discussion centers on having the students identify how to handle issues that arise while working in teams. 


\section{Negotiating}

Students need to be aware that negotiations occur in many different types of situations from customer issues to internal debates. Negotiating is tough because there are two sides, each with their own interests, objectives, and agendas. Role playing exercises are used to help students build win-win negotiating skills. Skilled negotiators build a reputation for being fair but firm. They create an atmosphere of trust and confidence, not doubt and suspicion.

\section{Time management}

Students need to develop time management skills in order to successfully conduct business in the future. Recognizing time robbers like the lack of information, impromptu tasks, unscheduled activities, procrastination, poor communication, and lack of sufficient planning is the first step in effectively managing time. Following a lecture on time management, students are asked to write down their weekly schedule. For two weeks, students are asked to record their actual day-to-day activities. The original schedule is then compared with their actual experiences. From this exercise, class discussion centers on developing team time management skills that will help them stay on track and on target.

\section{Conducting effective meetings}

Without good leadership, a meeting can become an unproductive waste of time. Poorly run meetings nearly always exhibit the same problems: no specific or clearly defined objective(s) for the meeting or the participants; no meeting agenda; unprepared leaders or participants; and the wrong choice of participants. Students are taught how to prepare for and run an effective meeting. Topics discussed include: Determining the objective of the meeting; determining who should participate; setting the agenda; preparing the plan of action for the meeting; using the agenda to keep the meeting on track; making decisions; assigning responsibilities; and following-up. Students need to understand that with preparation and an agenda, meetings are easier to keep on track. A meeting is not successful unless it brings about the intended results.

To integrate this learning into their existing team project, each team must develop an agreement among team members about how the team will operate. Some of the things that must be in the team contract include: when will team meetings be held, meeting attendance requirements, how will meetings be conducted as well as performance and quality of work requirements for each team member. A team contract is important to establish the norms of behavior expected by the team members early in the project and the contract helps to reduce misunderstandings during the performance stage.

\section{Examples of Courses with Team Projects}

Throughout our curriculum, students learn project management and teamwork skills by actually doing a project. Each project has a sponsor, either a local business or a faculty 
or staff member on-campus. In some cases, simulated projects are used. Figure 1 is an example of a project used in IET-418 Cost estimating. Student teams must take the project from the proposal stage to completion of the project goals. The project constitutes a major portion of the course grade. It is important for the instructor to receive feedback on how well each student performed as a team member. Some students become "social loafers" who try to let other team members do all the work. Each student is asked to evaluate their contribution as well as each team member's contribution to the project. This is done several times during the semester and the feedback is used, in part, in determining individual grades.

\section{IET 230L Work Measurement Lab}

This laboratory course requires students to work together in teams to perform several work measurement projects. Examples of projects include balancing assembly lines and setting time standards for work processes and mapping the flow of products through a facility. The term project for this course is a competition between student teams to design the most efficient workstation.

\section{IET 308 Production Management Methods}

This course teaches lean manufacturing and production and inventory control concepts. Student teams analyze and improve work cell designs and determine ways to control and reduce inventory costs.

\section{IET 322 Human Factors}

Students learn methods to improve the interface between the human and their environment. Human characteristics are studied to determine the best way of designing the task, product, workstation or other environmental feature to fit the human. Student teams analyze and improve various designs to improve the human-environment interface. Team projects include: developing computer data input screens for the local police department and redesigning a variety of manufacturing workstations.

\section{IET 332 Facilities Layout}

Students learn to design facilities for the most efficient flow of raw materials, work-inprocess, and completed stock through a work place. The term project for this class requires teams of students to design the layout for an 80,000 square foot manufacturing facility.

\section{IET 415 Management of Technical Organizations}

The Engineering Technology department, based on input from the organizations hiring Engineering Technology students and the ABET criteria, identified the need for ensuring that graduates understand team work and team management skills. One of the courses that could be redesigned to include teamwork was IET-415. Once a traditional 
organization and management course, this course was revamped to have four key outcomes, one of which is to develop a working knowledge of teams, teamwork, negotiation and personnel management in a globally diverse workforce. Teamwork topics discussed in this section of the course include time management, communication, teams and teamwork, change leadership, controlling to ensure results, and negotiation. Students work in teams to tackle negotiating problems, reinforcing their understanding of what it takes to successfully negotiate project ideas, salary increases, and customer/supplier issues.

\section{IET 418 Cost Estimating}

Students learn the fundamentals of cost estimating of labor, materials, and overhead requirements for projects, products, operations, and systems. The term project for this course requires student teams to prepare a bid proposal and estimate the cost of producing a new product, which includes the product cost and price.

\section{IET 420 Industrial and Environmental Safety}

This class requires that teams apply three key safety techniques to enhance safety in an area organization. These techniques include failure modes and effects analysis, preliminary hazard analysis and a variety of term projects including safety analyses of a local food bank, manufacturing work areas, a garage, a carwash, and a cleaning service.

\section{490 Senior Project}

In this capstone course, interdisciplinary student teams apply principles learned in previous courses to a major project for a local business. Student teams are expected to take the project from concept to the prototyping stage applying planning, scheduling, monitoring and controlling techniques. Teams prepare and deliver oral and written project proposals, status updates, and final reports for the management of the sponsoring organizations.

\section{Conclusions}

Teamwork cannot be effectively taught in a stand-alone course. It must be learned by experience over time. In many cases, students learn about teamwork in an early course and then do not apply the concepts until several years later, perhaps in the capstone course. It is well known that only a small amount of material is retained by students after completing a course. By integrating teamwork lectures and experiences throughout the curriculum, students understand better what it means to be an effective team member and team leader.

\section{References}


1. Maxwell, J.C., "The 17 Indisputable Laws of Teamwork," Nashville Tennessee: Nelson Business Publishing, 2001

2. Lencioni, P., “Overcoming the Five Dysfunctions of a Team,” San Francisco: Josey Bass, 2005

3. Smith, K. A., \& Imbrie, P. K., “Teamwork and Project Management,” New York: McGraw Hill, 2004

4. Prince, M., et al, “A Conceptual Framework for Progressively Developing Students' Team and Problem Solving Skills Across the Curriculum,” ASEE Proceedings, 2002, Session 2630

5. Quin, L., "Integrating Professional and Technical Skills Development in Tool Design Course for Manufacturing Engineering Technology Curriculum,” ASEE Proceedings, 2006, Session 276

5. Yost, S., Lane, D., \& Blandford, G., "RATS: Students Working in Teams, Do They Really Benefit?" ASEE Proceedings, 2006, Session 2306

6. Dunn, P. \& Pierce, B., "Introducing Project Management to Senior Civil Engineering Students," ASEE Proceedings, 2006, Session 1930

7. Krupar, JU. \& Suckarieh, G., "Leadership and Teamwork Education for Engineering and Technology Students," ASEE Proceedings, 2005

8. Adams, S. G., Vena, S. C., Ruiz-Ulloa, B. C., \& Pereira, F., “A Conceptual Model for the Development and Assessment of Teamwork," ASEE Proceedings, 2002

9. Scholtes, P. R., “The Team Handbook,” Jointer Associates, Inc., Madison WI, 1993

10. Philips, P. L., "So, You're Going to be a Member of a Team," Chemical Engineering Progress, pages 141-144, January 1997 


\title{
IET418 COST ESTIMATING
}

\section{TERM PROJECT}

\author{
Super-Tech Proposal
}

PURPOSE: To have the students simulate a real world situation involving cost estimating concepts and principles.

\section{PROJECT DESCRIPTION}

Hi-Tech Incorporated is soliciting bids for purchase of a new product. You are part of a team from SuperTech Plant No. 1, Inc that was formed to estimate the cost of producing the new product and to prepare a proposal in response to the Request for Proposal from Hi-Tech, Inc. The product is to be manufactured from metal bar stock that is two inches in diameter by 12 foot long. The material is medium carbon steel, and density of the material is 0.2885 pounds per cubic inch. On one end of the part, $3 / 16$ " is not usable as it is needed to square off the end. The material can be purchased for $\$ 2.26$ per pound and salvaged for $15 \%$ of the original cost. The long-term quantity required is 15,000 units, produced in lots of 1,000 units, which is the required weekly quantity. The company provides eight paid holidays and ten days of vacation. Four additional days are allowed for sick leave. FICA is at the rate for the current year, workmen's compensation is $2 \%$ of the first $\$ 25,000$, accident insurance is $\$ 1200$, and medical insurance is $\$ 800$. Turning and drilling are light machining and milling is heavy machining. The wage rate is $\$ 18.50$ per hour for the light machining department, $\$ 36.50$ per hour for the heavy machining department, and $\$ 25.00$ for other machining. Similar products have indicated an $87 \%$ learning rate. The calculated cycle time is assumed to be the time to produce the first part. There is a $90 \%$ utilization rate for all machines.

Your team will determine the processing methods to produce the product. This must be fully documented in each of the project task deliverables, your written report and the presentation. Identify number of employees, type of equipment, tooling, etc., that you will use and the time to produce the required longterm quantity. The project tasks are as follows:

\section{PROJECT TASK}

1. Project plan

2. Time study

3. Material cost

4. Productive hour calculations/tables

5. Status update Report

6. Operations cost calculations/sheet

7. Final Proposal Report

8. Oral presentation

\begin{tabular}{ll} 
DUE DATE & Points \\
\hline $3-12$ & 15 \\
$3-18$ & 10 \\
$3-22$ & 5 \\
$3-24$ & 10 \\
$3-29$ & 5 \\
$4-7$ & 30 \\
$4-21$ & 15 \\
$4-21$ & 10
\end{tabular}

Show the detailed calculations for each of the above, where necessary. Identify the project manager for each of the above tasks on the peer evaluation form. The project manager duties will be rotated for each assignment.

\section{Figure 1 IET-418 Cost Estimating Team Project}

